POLITYKA ENERGETYCZNA - ENERGY POLICY JOURNAL

$2021 \uparrow$ Volume $24 \uparrow$ Issue $3 \uparrow 43-60$

DOI: $10.33223 / \mathrm{epj} / 141867$

Artur Dyczko ${ }^{1}$, Paweł KamiŃski ${ }^{2}$, Kinga StecuŁA ${ }^{3}$, Dariusz Prostański ${ }^{4}$, Michał KopaCz ${ }^{5}$, Daniel KowoL ${ }^{6}$

\title{
Thermal and mechanical energy storage as a chance for energy transformation in Poland
}

AbSTRACT: The objective of the European Green Deal is to change Europe into the world's first climate-neutral continent by 2050 . Therefore, European countries are developing technological solutions to increase the production of energy from renewable sources of energy. In order to universally implement energy production from renewable energy sources, it is necessary to solve the problem of energy storage. The authors discussed the issue of energy storage and renewable energy sources, reviewing applied thermal and mechanical energy storage solutions. They referred to the energy

\footnotetext{
$\triangle$ Corresponding Author: Kinga Stecuła; e-mail: kinga.stecula@polsl.pl

${ }^{1}$ Mineral and Energy Economy Research Institute of the Polish Academy of Sciences, Kraków, Poland; ORCID iD: 0000-0002-5613-0395; e-mail: arturdyczko@min-pan.krakow.pl

2 Faculty of Mining and Geoengineering, AGH University of Science and Technology, Kraków, Poland; ORCID iD: 0000-0002-1450-5881; e-mail: pkamin@agh.edu.pl

${ }^{3}$ Przedsiębiorstwo Budowy Szybów SA, Tarnowskie Góry, Poland; ORCID iD: 0000-0002-6271-2746; e-mail: kinga.stecula@polsl.pl

${ }^{4}$ KOMAG Institute of Mining Technology, Gliwice, Poland; ORCID iD: 0000-0002-9047-9646; e-mail: dprostanski@komag.eu

${ }^{5}$ Mineral and Energy Economy Research Institute of the Polish Academy of Sciences, Kraków, Poland; ORCID iD: 0000-0001-6475-8206; e-mail: kopacz@meeri.pl

${ }^{6}$ KOMAG Institute of Mining Technology, Gliwice, Poland; ORCID iD: 0000-0001-5547-376X; e-mail: dkowol@ komag.eu
}

2021. The Author(s). This is an open-access article distributed under the terms of the Creative Commons Attribution-ShareAlike International License (CC BY-SA 4.0, http://creativecommons.org/licenses/by-sa/4.0/), which permits use, distribution, and reproduction in any medium, provided that the Article is properly cited. 
sector in Poland which is based mainly on mining activities. The method that was used in this paper is a review of thermal and mechanical energy storage solutions. In industrial practice, various solutions on energy storage are developed around the world. The authors reviewed those solutions and described the ones which currently function in practice. Hence, the authors presented the good practices of energy storage technology. Additionally, the authors conducted an analysis of statistical data on the energy sector in Poland. The authors presented data on prime energy production in Poland in 2004-2019. They described how the data has changed over time. Subsequently, they presented and interpreted data on renewable energy sources in Poland. They also showed the situation of Poland compared to other European countries in the context of the share of renewables in the final gross energy consumption.

KeYwords: energy storage, energy, renewable energy sources, energy transformation, Poland

\section{Introduction}

Energy is the fundamental factor that determines economic and social development. It constitutes a highly important need of society. World economic development and population growth led to a greater need for energy, especially for electricity and heat (Mikhno et al. 2021). Due to this need and, at the same time, increasing environmental awareness, investing in new types of energy was required. In the $21^{\text {st }}$ century, renewable energy sources (RES) began to be developed. Countries began to set certain targets for the use of renewable energy and the development of technology that allows its use on a larger scale (Cader et al. 2021a). Regarding the Member States of the European Union, a specific share of energy has been set for energy from renewable sources. The directive, updated in 2018, aimed for $32 \%$ share of renewables in the European Union energy mix by 2030. However, an early draft (May 2021) of the upcoming directive confirms the objective of sourcing $38-40 \%$ of this energy 2030 (Euractive 2021). RES are an alternative to fossil fuels and their use on a larger scale is expected to reduce greenhouse gas emissions and countries' dependence on fossil fuel markets and diversify energy supplies (Olczak et al. 2021c; Wróbel et al. 2019).

In recent decades, the Polish energy market has been based on conventional sources that include hard coal, lignite, natural gas, and crude oil. This is related to natural deposits in Poland especially of hard coal and lignite (Kryzia and Pepłowska 2019; Stecuła and Brodny 2018a). However, Poland is also investing more and more in renewable energy sources (Stecuła and Brodny 2017a). One solution in the field of RES is thermal and mechanical energy storage (Matuszewska et al. 2020). There are not many projects in the world that enable energy storage yet, but this is a very promising direction. At present the Polish economy and the energy market are facing many changes. On the one hand, those changes can be a chance for Poland but on the other hand, they might be a big threat. Energy transformation assumes moving away from coal and increasing the use of renewable energy sources. Therefore, Poland needs modern and 
ground-breaking technological solutions that provide stable, efficient, and proper energy supply and simultaneously use RES.

\section{Theoretical Framework}

\subsection{Energy sector in Poland}

The World Energy Council has divided the world's energy resources into two categories: renewable and non-renewable (Soliński 2004). Non-renewable fuels constitute the basic source of the world's primary energy supply. They consist of:

$\downarrow$ Hard coal and lignite (brown coal);

$\checkmark$ Crude oil;

^ Oil shales;

$\downarrow$ Tar sands and oil sands;

$\downarrow$ Natural gas;

$\uparrow$ Uranium;

The renewable energy sources are represented by:

$\checkmark$ Hydropower;

$\downarrow$ Fuel wood;

$\downarrow$ Biomass other than wood (Mirowski et al. 2020);

$\uparrow$ Peat;

$\downarrow$ Solar energy;

- Geothermal energy (Ciapała et al. 2021);

$\downarrow$ Wave and tidal energy;

४ Oceans' thermal energy.

The geological assessment of the fossil fuels reserves is still incomplete. The methods and technologies of deposit recognition are evolving. Thus, by increasing the depth of surveys, new deposits may be discovered. Moreover, many deposits are located within places that are not easily accessible, such as Antarctica (Soliński 2004). Poland's primary energy production relies on fossil fuels (Kaszyński et al. 2019). The most important Polish energy carrier is hard coal (Gawlik 2013; Mokrzycki and Gawlik 2013). There are two types of coal: energy coal and coking coal (Kopacz et al. 2020). Coal resources dominate in the national structure of energy resources. Figure 1 shows primary energy production in Poland in 2004-2019. The subsequent most important energy carrier is lignite. From 2004 to 2019, the share of hard coal in total production decreased. In recent years, the mining industry has undergone a lot of social pressure and competition in the global market. To survive, it has been forced to take actions to optimize costs and improve effectiveness (Palka and Stecuła 2019; Stecuła 2018; Stecuła and Brodny 2018b, 2017b). 
However, it is worth noticing that the extraction of hard coal from domestic deposits provides energy security and competitiveness to Poland. Hard coal deposits are located in Poland in three basins: the Upper Silesian Coal Basin, the Lublin Coal Basin and the Lower Silesian Coal Basin. Currently, coal is excavated in the first two basins. The Upper Silesian Coal Basin contains over $80 \%$ of documented resources of hard coal in Poland (Państwowy Instytut Geologiczny 2020).

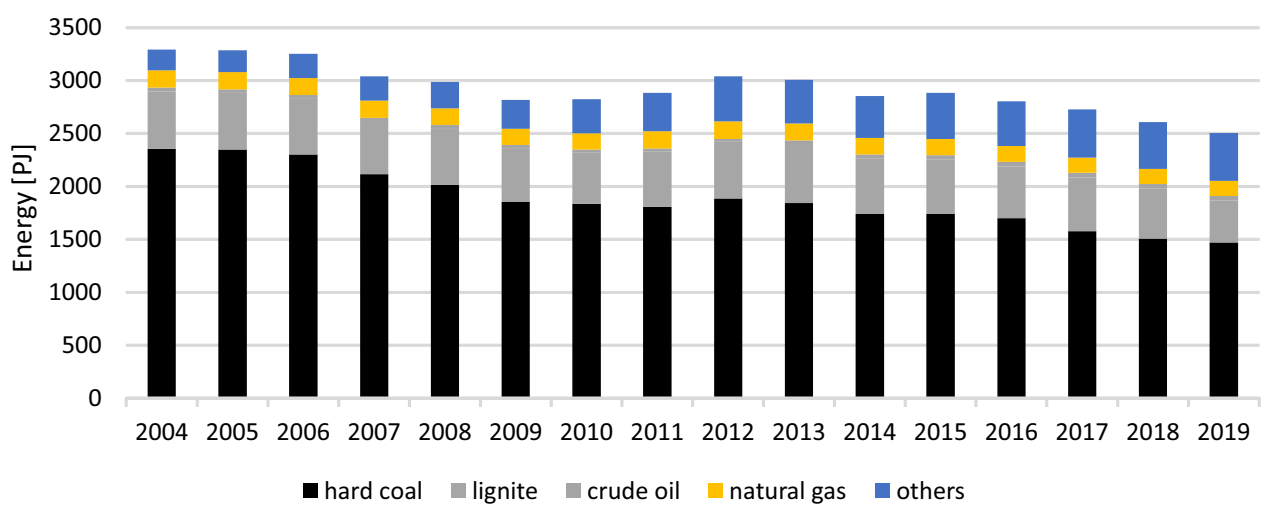

Fig. 1. Primary energy production in Poland

(own study based on: Agencja Rynku Energii SA 2020; Statistics Poland 2020a)

Rys. 1. Produkcja energii pierwotnej w Polsce

The volume of hard coal production has had a downward trend in recent years. In 2007, production amounted to 89.8 million tons, and in 2020 it was already around 35 million tons less. Import amounted to a minimum value of 8.2 million tons in 2015, and a maximum value of 19.7 million tons in 2018. Figure 2 shows coal production, sales and import in Poland in 2007-2021. The decreasing trend in hard coal production is due to investments in renewables and the general global tendency to decarbonize the economy. Countries strive to meet energy needs while minimizing the use of non-renewable resources (Orzeł 2020). Poland is struggling with many environmental problems, that result from activities in the field of conventional energy, mainly air (Frankowski 2020; Stecuła and Brodny 2017a; Woźniak and Pactwa 2018), water and soil pollution (Cabała et al. 2020) and noise (Paszkowski and Loska 2017). One of the biggest issues is the phenomenon of so-called "low-stack emission" (Graboś and Żymanowska-Kumon 2014) which is affected by mining operations (Stecuła and Tutak 2018) and insufficient interest in and the use of renewables (Klojzy-Karczmarczyk and Mazurek 2009). Poland bears annual costs of USD 21-38 billion (i.e., PLN 79-144 billion) due to smog (Airly 2020). Moreover, it is estimated that around 45 thousand people die due to air pollution each year in Poland (Airly 2020). 


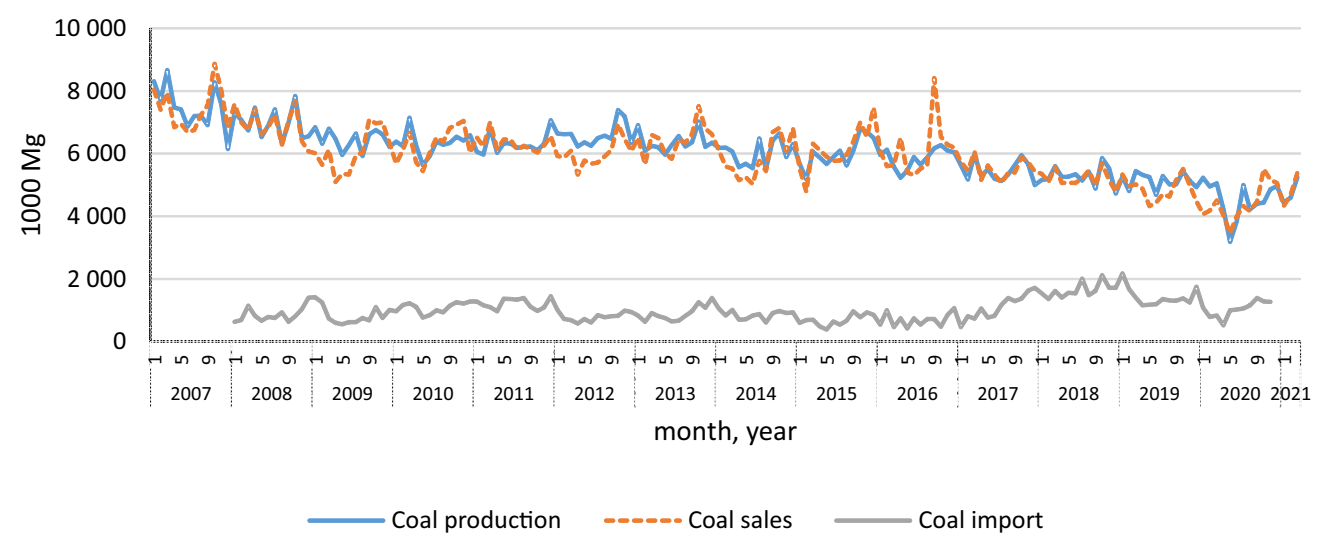

Fig. 2. Coal production, sales and import in Poland in 2007-2021 (own study based on: Energy Instrat 2021)

Rys. 2. Produkcja, sprzedaż i import węgla w Polsce w latach 2007-2021

\subsection{RES in Poland}

The objective of the European Green Deal (European Commission 2019) is to change Europe into the world's first climate-neutral continent by 2050 . The use of renewables has many benefits, especially related to reducing the negative impact on the natural environment, primarily reduction in greenhouse gas emissions. Moreover, the results of investing in renewables are a reduced dependency on fossil fuel markets and the diversification of energy supplies (Cader et al. 2021b; Olczak et al. 2020, 2021b). According to the European Green Deal, decarbonizing the energy system is crucial to reach European climate objectives in 2030 and 2050. The production and use of energy across economic sectors account for over $75 \%$ of the EU's greenhouse gas emissions. A power sector has to be developed - that is based on renewables, complemented by the rapid phasing out of coal and decarbonizing gas. Simultaneously, the energy supply must be secure and affordable for consumers (Olczak et al. 2021a). To make this happen, it is important to ensure that the European energy market is fully integrated and interconnected and uses the new energy production technologies (European Commission 2019; Koval et al. 2019; Żelazna et al. 2020).

Figure 3 shows the share of renewable energy in final gross energy consumption in 2019. The countries, whose share of renewable energy sources is the highest include: Iceland, Norway, Sweden, Finland, Latvia, Denmark, Austria, Estonia, Portugal, Croatia, Lithuania, Romania, Slovenia, and Bulgaria. This share is above 21\%. In the case of Poland, this share was $11.16 \%$ in 2018. In turn, in 2019 this share increased to 12.18\% (Statistics Poland 2019, 2020a, 2020b).

In the case of Poland, the main reasons for the structure of obtaining energy from renewables are geographical conditions and the resources that can be managed. Energy obtained from renewables mainly comes from solid biofuels (68.88\% in $2018,65.56 \%$ in 2019), wind energy 


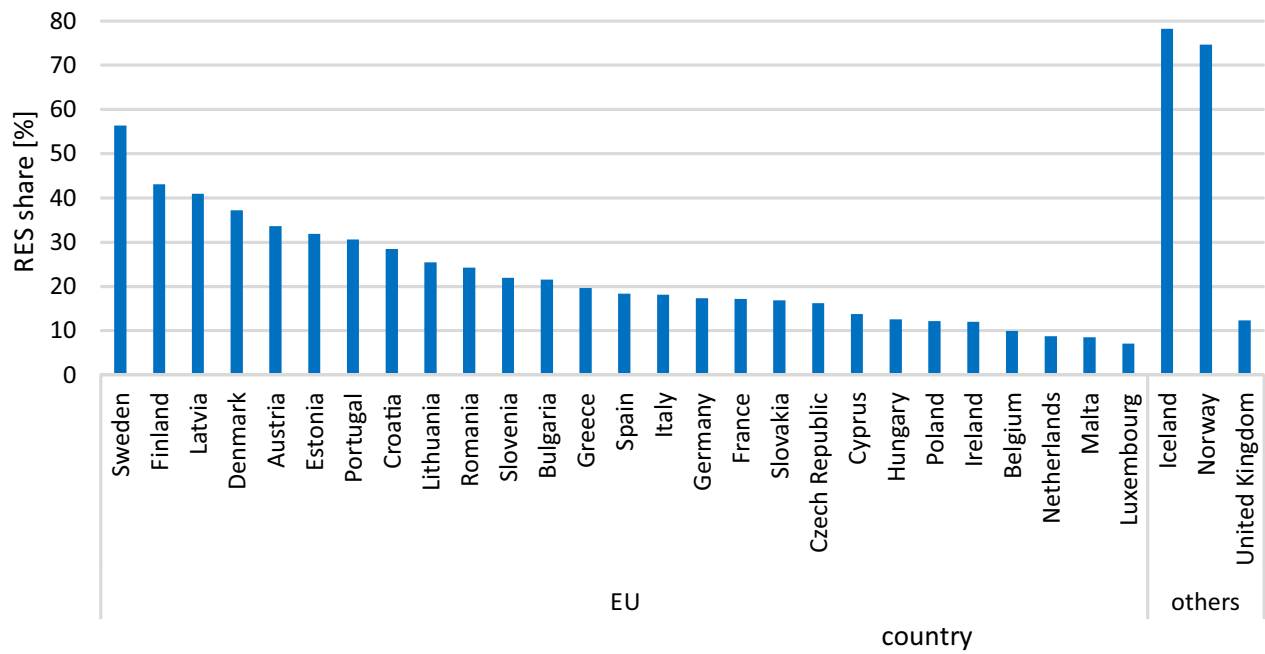

Fig. 3. Share of renewable energy in final gross energy consumption in 2019 [\%]

(own study based on: European Environmental Agency 2021)

Rys. 3. Udział energii odnawialnej w końcowym zużyciu energii brutto w 2019 r. [\%]

(12.55\% in 2018, $13.72 \%$ in 2019) and liquid biofuels (10.33\% in 2018, $10.36 \%$ in 2019) (Statistics Poland 2020b). Figure 4 shows the structure of energy from renewable sources by carriers in Poland in 2019. The structure of energy consumption from renewables consists of a relatively large share $(54.86 \%)$ of final consumers and a smaller (45.13\%) of its use for the energy transformation input. These proportions show that energy carriers from renewables are less often used by industrial installations, where - because of energy transformations - derivative energy carriers, such as electricity and heat, are produced, and then delivered to consumers.

The total energy value of acquired primary energy from renewable sources in 2018 was 367,091 TJ and in 2019 - 396,498 TJ. The details about energy from renewable sources in 2015-2019 are shown in table 1 . In 2019, the highest production and import of RES among the analyzed years were observed. In recent years, the export of RES has gradually decreased. Inland consumption increased by $6.72 \%$ in 2019 . The transformation sector was mainly related to the main activity of the electricity producer (CHP plants), then blending to motor gasoline/diesel, and autoproducer electricity (CHP plants) or ORC (Matuszewska et al. 2017; Matuszewska and Olczak 2020). Final energy consumption was characterized by an upward trend in the analyzed period. Every year the greatest parts of the industry sector were paper, pulp and printing and wood and wood products. In terms of production volume, solar energy has developed significantly. Solar energy production recorded a very large increase in 2019 (it amounted to over 5,500 TJ) - it was higher by over $60 \%$ compared to 2018. The production of hydro energy was the highest in 2017 (over 9,000 TJ) among the analyzed years. The production of wind energy was raised by almost $20 \%$ in 2019 compared to 2018 . The energy production from heat pumps increased gradually 


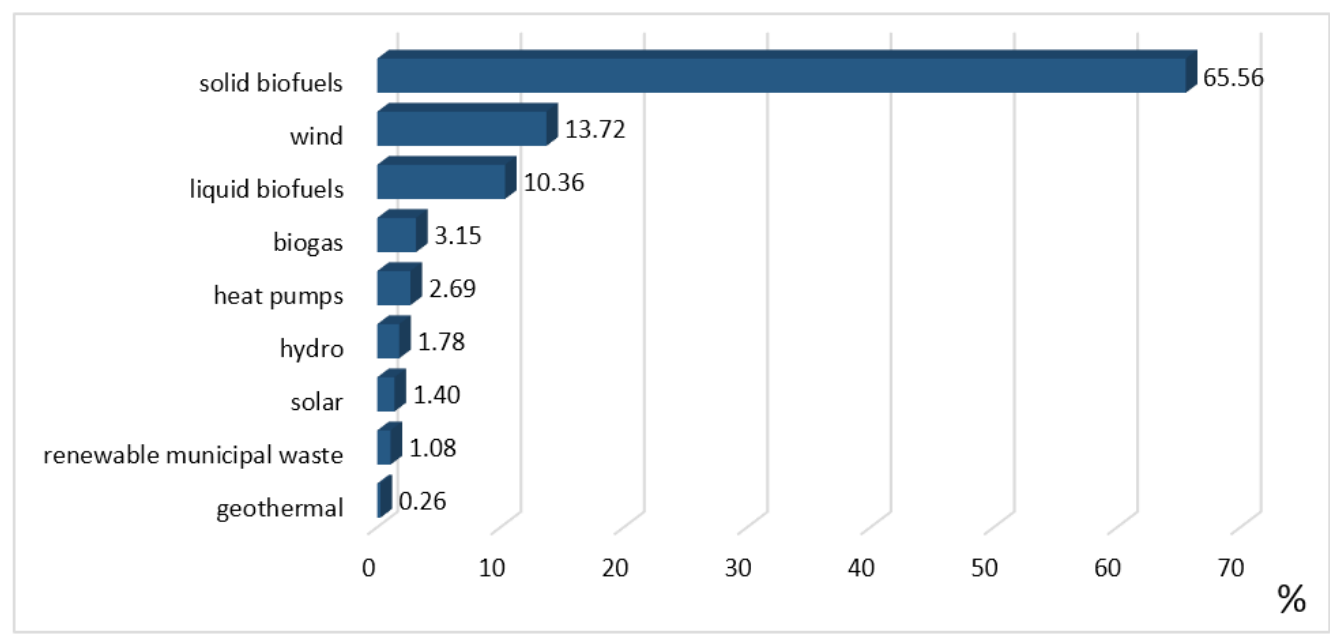

Fig. 4. The structure of energy from renewable sources by carriers in Poland in 2019 (own study based on: Statistics Poland 2020b)

Rys. 4. Struktura energii ze źródeł odnawialnych według nośników w Polsce w 2019 r.

TABLE 1. Energy from renewable sources in Poland in 2015-2019 [TJ]

TABELA 1. Energia ze źródeł odnawianych w Polsce w latach 2015-2019 [TJ]

\begin{tabular}{|l|r|r|r|r|c|}
\hline \multicolumn{1}{|c|}{ Specification } & \multicolumn{1}{c|}{2015} & 2016 & 2017 & \multicolumn{1}{c|}{2018} & 2019 \\
\hline Indigenous Production & 375,564 & 383,808 & 388,483 & 378,049 & 396,498 \\
\hline Imports (+) & 36,934 & 34,850 & 31,821 & 37,621 & 45,861 \\
\hline Exports (-) & 30,947 & 45,288 & 39,298 & 28,141 & 26,758 \\
\hline Stock Changes (+/-) & -422 & -334 & -110 & -730 & -920 \\
\hline Inland Consumption & 381,129 & 373,037 & 380,897 & 386,798 & 414,682 \\
\hline Transformation Sector & 175,231 & 154,133 & 154,924 & 161,093 & 187,157 \\
\hline Energy Sector & - & 32 & 23 & 36 & 20 \\
\hline Final Energy Consumption of which: & 205,898 & 218,872 & 225,950 & 225,669 & 227,504 \\
\hline Industry Sector & 59,032 & 65,170 & 70,976 & 71,912 & 78,323 \\
\hline Construction & 6 & 10 & 8 & 21 & 22 \\
\hline Transport Sector & 64 & 180 & 2 & & 34 \\
\hline Other Sectors & 146,797 & 153,512 & 154,964 & 153,703 & 147,464 \\
\hline
\end{tabular}

Own study based on: (CSO 2020).

from 2015 to 2019 . The largest increase took place from 2018 (8,958 TJ) to $2019(10,681 \mathrm{TJ})$ - it was almost 20\% (CSO 2020).

To limit the negative impact of the mining operation on the natural environment and meet the EU's environmental objectives, Poland needs to increase its activity in the field of renewables. Even though modern research in Poland relates mainly to the development of technologies 
within fossil fuels (Bartoszek et al. 2021; Dyczko and Malec 2021; Kamiński 2021a, 2021b; Kamiński et al. 2021; Pedchenko et al. 2018; Stecuła and Brodny 2017b), there is a big need and support for investment in renewables (Komorowska et al. 2020; Olczak and Komorowska 2021). The modern and beneficial technology in this area is thermal energy storage. The next paragraph describes what thermal energy storage is.

\subsection{Thermal energy storage}

The challenge of storing energy has been undertaken for many years. The first batteries were used in the early nineteenth century, and the first pumped-storage energy started its operation in 1920 (Rafał and Grabowski 2021). In Central European countries, about 2/3 of the solar radiation heats the surface between May and September. On the other hand, the heating season is usually between October and April, making it impossible to use solar energy as a source of thermal energy efficiently. The solution to this problem is thermal energy storage, which enables balancing the production and demand for thermal energy in the warm and cold months (Kadar 2014; Mangold and Deschaintre 2016). There are the following types of underground energy storage (Mangold and Deschaintre 2016):

$\checkmark$ Tank thermal energy storage (TTES);

$\checkmark$ Pit thermal energy storage (PTES);

$\checkmark$ Borehole thermal energy storage (BTES);

$\checkmark$ Aquifer thermal energy storage (ATES).

Figure 5 shows the types of energy storage.

Most of the thermal energy storages are built underground. This is due to the following (Mangold and Deschaintre 2016):

$\downarrow$ Energy storages are often built in the vicinity of residential areas (reduction of the impact on the landscape);

$\downarrow$ The rock mass provides additional thermal insulation;

$\checkmark$ In some cases, the rock mass itself is an energy store (BTES and ATES);

$\checkmark$ Rock mass pressure outside the storage enables water pressure compensation inside the storage (TTES).

Before underground thermal energy storage constructing, it is necessary to carry out a detailed hydrogeological analysis, taking the stratigraphy, the location of groundwater tables, soil permeability, and the size and direction of groundwater flows into account (Wyrwicki 2004). Different hydrogeological conditions must be met for each type of underground energy storage (Dychkovskyi et al. 2019; Mangold and Deschaintre 2016; Matuszewska et al. 2020).

The basic element of the TTES is an underground tank, usually made in a reinforced concrete housing (prefabricated or made in situ). The tank is filled with water, which is the accumulation medium. Thermal energy can be charged and extracted in two ways: directly by pumping hot water or indirectly using heat exchangers. The TTES usually cooperate with large systems of solar 


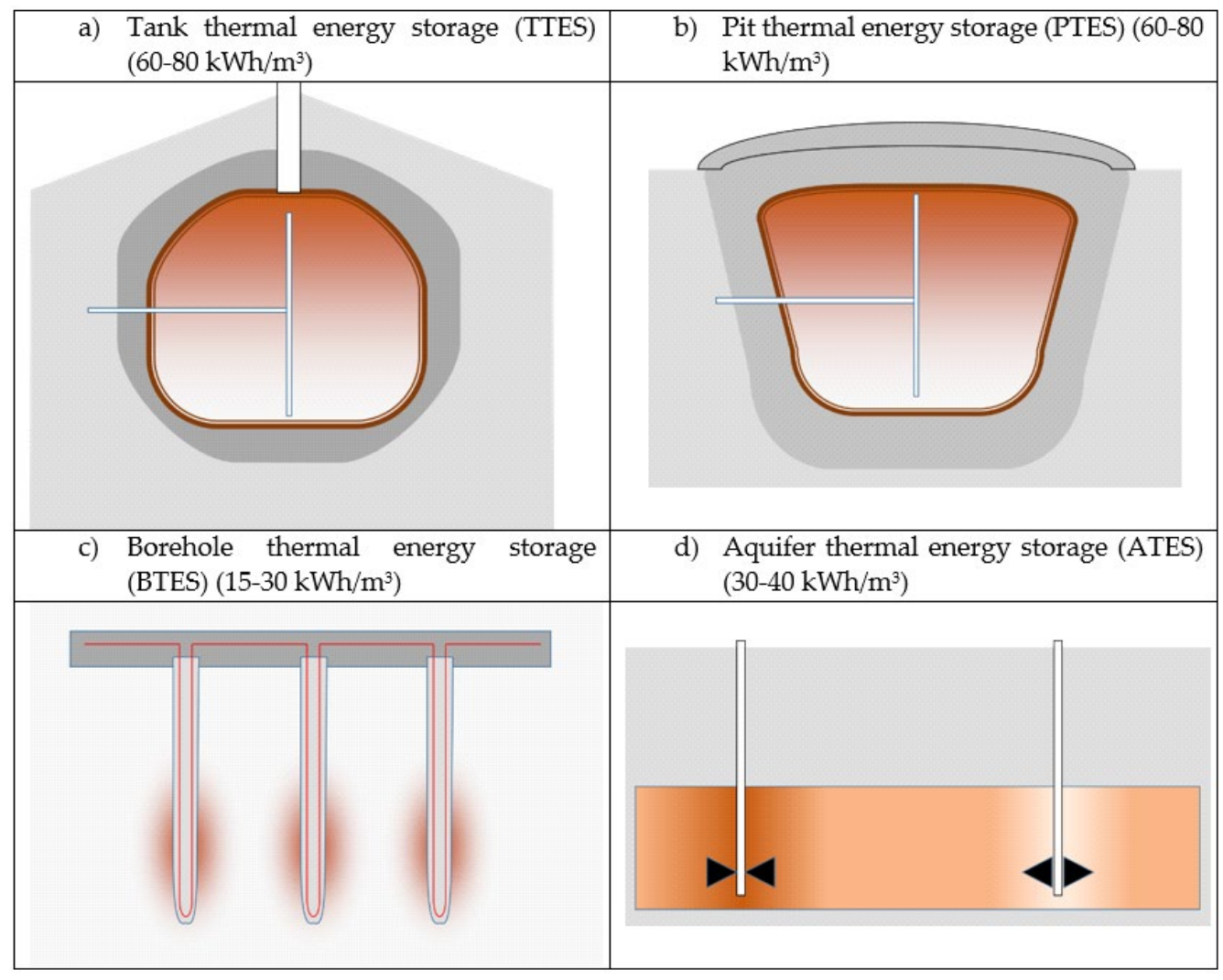

Fig. 5. The types of underground energy storage (own study based on: Schmidt et al. 2018)

Rys. 5. Typy podziemnych magazynów energii

collectors, they can also be an element of hydraulic circuits of a combined heat and power plant. The case of the tank must be able to transfer external loads, coming from the rock mass, and internal loads, coming from water. Since these loads are counterbalanced, it is possible to limit the thickness of the case in relation to the thickness of the walls of typical above-ground tanks. In order to reduce heat loss, the tank is additionally insulated with mineral wool, glass wool, or polyurethane (Kwestarz 2016; Mangold and Deschaintre 2016).

The PTES consist of a tank located below the ground surface and insulated with foil. As with the TTES, the PTES can be loaded and unloaded directly or indirectly. To reduce heat loss, the tank is built up from above with a fixed or floating accumulation medium on the surface. The accumulation medium is a mixture of water and gravel. The use of this type of medium limits the storage capacity. The volume of the gravel-water tank must be about $30 \%$ larger than that of the water tank to obtain the same thermal capacity (Kwestarz 2016; Mangold and Deschaintre 2016; Steinmann et al. 2019). Compared to other storages, PTES has the lowest specific investment cost due to economies of scale (Schmidt et al. 2018). 
In the BTES, heat is stored directly in the rock mass. The basic element of this type of storage is U-type heat exchangers, built-in boreholes with a length of 30 to $200 \mathrm{~m}$. When charging, the hot medium, flowing through the heat exchangers, gives off heat to the rock mass - in this situation, the medium flows from the inside to the outside of the storage, thus allowing high temperatures in the central part to be reached. During discharge, heat is taken from the rock mass by the cool medium, while the flow direction of the medium is reversed. To use the BTES, it is necessary to have a low-permeable rock mass, characterized by high heat capacity. This condition is well met by clay formations. The volume of the BTES tank must be approximately 3-5 times greater than the volume of the TTES tank to obtain the same heat capacity (Abbas et al. 2020; Kwestarz 2016; Mangold and Deschaintre 2016). BTES has low costs but high losses (Schmidt et al. 2018).

Heat is stored in the ATES using natural groundwater reservoirs - the accumulation medium is porous soil and water that fills it. The basic element of the ATES is two well systems of different depths. During charging, water is pumped from the "cold" well, heated e.g., by solar collectors, and pumped underground by the "warm" well. When discharging, the water flow direction is reversed. A thermal front, which moves depending on temperature changes, is created between the "warm" and "cold" parts of the tank. The use of the ATES requires specific hydrogeological conditions. The aquifer must have high porosity and a filtration rate and be insulated at the top and bottom by impermeable layers (Kwestarz 2016; Mangold and Deschaintre 2016). Figure 6 shows the ATES.

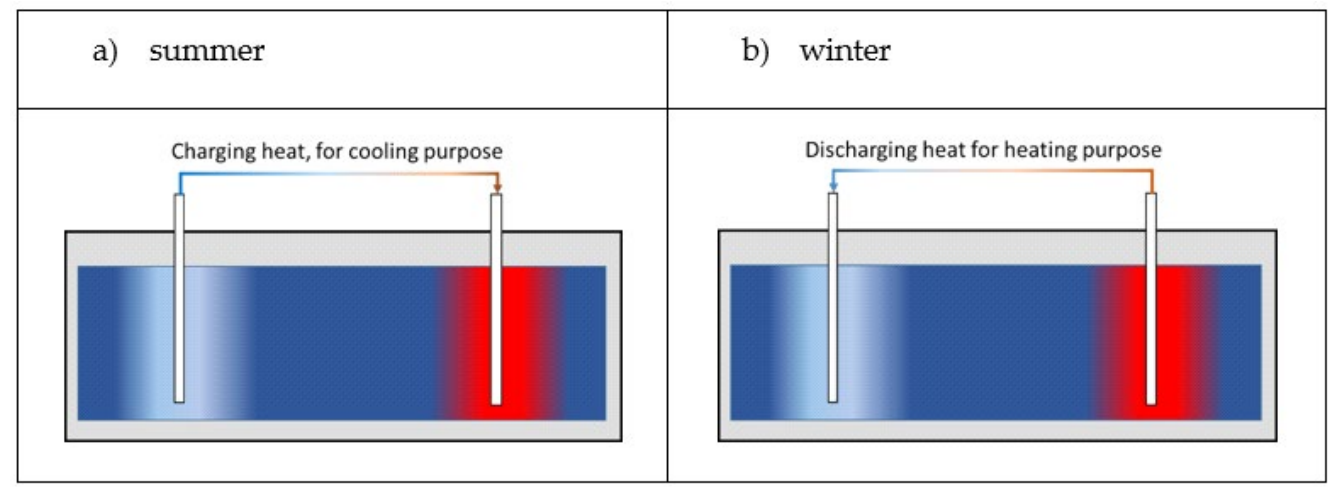

Fig. 6. Aquifer thermal energy storage

(own study based on: Possemiers 2014)

Rys. 6. Magazyn energii cieplnej warstwy wodonośnej

Solving the problem of energy storage is necessary for the universal implementation of electricity production from renewable sources. The use of ecological wind and solar energy is related to the difficulty of balancing supply and demand. Therefore, in countries where the energy mix is largely composed of renewable sources, two situations may arise. On the one hand, on some days all energy needs are covered by wind and solar power plants. On the other hand, there are 
so-called blackouts, during which the energy demand exceeds the supply, and it is necessary to use conventional sources. It should be noted that a situation where energy production exceeds demand is not favorable either. There are situations where the surplus electricity has to be transferred abroad, while the cost of the operation is borne by the producer (Kubiński and Szabłowski 2020; Kwestarz 2016).

\section{Review of the energy storage solutions}

The classic way of storing energy is typical lithium-ion batteries. Nevertheless, the possibility of using such solutions in the power industry is limited by the problems associated with the high cost and low durability of batteries. Moreover, other problems are limited service life and a future problem with utilization (Belu 2019). In response to the described problem, the British start-up Gravitricity has developed an energy storage technology based on the use of gravity. It is an extension of the existing technology used in pumped storage power plants which are mechanical energy storage based on water flowing between the two levels. During periods when the energy demand exceeds the supply, pumped storage power plants pump water to the upper level, thus obtaining potential energy. In the period of increased demand for energy, water is drained through pipelines to the lower level, and its kinetic energy is converted into electricity through turbines. The construction of pumped storage power plants is profitable only if the power of the designed installation is very high (Gravitricity 2020).

The system developed by Gravitricity is based on a winch system, used to store energy in the form of potential energy using large loads pulled into the shaft area. For this purpose, the existing mine shafts, left over from the closed mines can be used. When there is an increase in energy demand, the weights are lowered and their potential energy is converted into kinetic energy, which is then converted into electrical energy. Therefore, charging a gravity-based battery is lifting the weight up the shaft, and discharging it lowering the weight down the shaft. The idea for the Gravitricity system was developed by company founder Peter Fraenkel, the designer of the first tidal turbines used on an industrial scale (Gravitricity 2020).

The weights must be equipped with a guiding system consisting of taut large diameter ropes to prevent the loads from deflecting towards the sides of the shaft. The service life of the Gravitricity energy storage system is at least 50 years. In addition, it is to be characterized by a very high efficiency of $80-90 \%$. It should be noted that the efficiency of energy storage systems is a very important parameter that determines the size of losses. Moreover, the costs of the Gravitricity system are lower than the system based on lithium batteries with similar parameters. The Gravitricity system can generate electricity with a capacity of 1 to even $20 \mathrm{MW}$ with output duration from 15 minutes to 8 hours. While the weight system itself is an extremely efficient means of storing energy, the storage capacity can be further enhanced by increasing the air pressure in the shaft and thus creating a Compressed Air Energy Storage (CAES). Compressing the air in the 
shaft includes making an airtight plug and supplementing the shaft case with air-impermeable material (Gravitricity 2020).

Gravitricity is currently building a demo platform for its project. The 16-meter-high structure with a total output of $250 \mathrm{~kW}$ is being built in Scotland and connected to the local power network. If it is successful, the next step will be to make a full prototype in the mine shaft. Further plans include the construction of prototype energy storage facilities in South Africa, Australia, and European countries. If the use of this technology in the existing mine shafts is verified as an effective solution, subsequent shafts, which are ultimately intended to be part of the energy storage, will be built near cities, industrial plants, wind farms and solar power plants. In 2019 and 2020, the company received large funds to analyze the possibility of using disused mining shafts in South Africa for the implementation of the system. However, work has been delayed significantly due to the COVID-19 pandemic and the economic crisis (Gravitricity 2020; Holder 2020).

The technology developed by Gravitricity is not the only energy storage system based on gravity. Mountain Gravity Energy Storage (MGES), like the Gravitricity system, is based on lifting a certain mass during charging and lowering this mass during discharging. However, instead of loads in disused mine shafts, it uses a mass of sand, gravel, or other material located on a mountain peak. An international team, responsible for developing this technology, has proved that it is suitable for inexpensive energy storage over long periods of time (Davies 2020; Hunt et al. 2020).

Another system, developed by Energy Vault, uses a six-arm crane on top of a 33-story tower. The method of energy storage is similar to the Gravitricity system, but in this case, concrete blocks are used as weights. An important element of the system is the use of software that automates the entire process, controls cranes, and manages energy resources depending on the current demand. The cost of this storage is estimated at USD 7-8 million (Hussein et al. 2004).

The Swiss company Rehau offers solutions that use the road infrastructure as a source of thermal energy. In summer, surfaces made of mineral-asphalt mixtures heat up to temperatures of up to $60^{\circ} \mathrm{C}$, causing deterioration of the mechanical properties of the surface. In winter, surfaces are covered with snow and ice, increasing the risk of road accidents and infrastructure maintenance costs. The solution to this problem is systems of thermal collectors built into the surface, connected with PE-Xa probes, used for underground storage of thermal energy. In summer, solar heat is extracted from the asphalt surface and stored underground. Then, the stored heat is used in winter to remove snow and de-icing the road (REHAU 2011).

A similar system can also be used in underground construction by installing heat collectors in the tunnel cases. In this variant, the heat from the collectors is transferred to the heat pumps and used in other applications. This type of solution has been successfully implemented in the Jenbach tunnel in Austria. The energy output ranged from 10-15 W/m $\mathrm{m}^{2}$, while the extracted heat was used to heat buildings above the tunnel (REHAU 2011).

Similar solutions could also be applied in mining constructions. The exhaust shafts of underground coal and metal ore mines remove enormous amounts of heat from the rock mass. The 
amount of heat increases with the increasing depth of exploitation. The system described above may be a solution that can make it possible to retrieve at least some of the heat released from the rock mass during underground mining activities.

The development of efficient methods of energy storage is a significant problem of the modern world. It is a key to increase the share of renewable energy sources in the energy mix. Energy storage is a buffer between the producer and the consumer of electricity, and it balances the differences between supply and demand. The use of energy storage will undoubtedly bring many benefits.

According to Gravitricity, their energy storage system can provide power to more than 13,000 households for two hours. If necessary, this solution can provide a short-term impulse of very high power (loads can be lowered down the shaft in a very short time). The current frequency in the energy network must be stabilized at $50 \mathrm{~Hz}$ - and the Gravitricity system can deliver a full -power impulse in less than one second. The response time of gravity-based storage is similar to that of a lithium-ion battery-based system. Unlike electrochemical batteries, Gravitricity can be loaded and unloaded many times a day without affecting performance. Analysts from Imperial College in London calculated that the implementation of the Gravitricity system will be a much cheaper solution compared to currently used solutions, including those based on lithium-ion batteries. At present, the potential of shafts in deep South African mines is being assessed (Gravitricity 2020; Holder 2020).

\section{Conclusions}

The effective use of renewable energy sources, for both heat and electricity, is inseparably linked with the need to use efficient methods of energy storage. This is due to the significant differences between the periodic energy demand and its production from renewable sources. One of the biggest disadvantages of RES is their dependence on changing weather conditions. The production of energy from fossil fuels is much more flexible in this field and makes it possible to correlate production with periodic energy demand. For this reason, an effective solution is to combine both RES and energy storage solutions.

The basis of the Polish energy sector is fossil fuels, the use of which has a negative impact on the natural environment, especially the air. For this reason, energy transformation is indispensable in Poland. This transformation is going in two main directions. The first is to move away from coal, and the second is to introduce new energy sources - mainly renewables. The energy transformation is a change in the energy system, both in energy production sources and its distribution. Energy storage meets these needs. It should be emphasized that the solutions described above have a potential for application in Poland. Currently, the Polish mining industry is planning to close coal mines. In reference to this, the possibility of using the existing infrastructure for the development of green energy should be considered. 
The underground energy storage, described in the article, the effectiveness of which has been tested and confirmed, is an essential element of the heating system, enabling the effective and economical use of renewable and waste energy. The idea of the TTES and the PTES can be used in mining areas. The existing mining infrastructure, related to an underground and opencast mining operation, should be the starting point for building energy storage. As a result, the investment costs of energy storage can be reduced.

\section{References}

Abbas et al. 2020 - Abbas, Z., Chen, D., Li, Y., Yong, L. and Wang, R.Z. 2020. Experimental investigation of underground seasonal cold energy storage using borehole heat exchangers based on laboratory scale sandbox. Geothermics 87, 101837.

Agencja Rynku Energii SA 2020. Primary Energy Balance in 2004-2019 (Bilans Energii Pierwotnej w latach 2004-2019). Warszawa (in Polish).

AIRLY, 2020. Oddychaj Polsko. Raport o stanie powietrza. [Online] https://airly.org/pl/raport-jakosci-powietrza/ [Accessed: 2021-09-09].

Bartoszek et al. 2021 - Bartoszek, S., Stankiewicz, K., Kost, G., Ćwikła, G. and Dyczko, A. 2021. Research on Ultrasonic Transducers to Accurately Determine Distances in a Coal Mine Conditions. Energies 14(9), 2532.

BeLu, R. 2019. Energy storage for electric grid and renewable energy application. In: Energy Storage, Grid Integration, Energy Economics, and the Environment. CRC Press Taylor \& Francis Group, Boca Raton, FL, USA, pp. 29-33.

Cabala et al. 2020 - Cabala, J., Warchulski R., Rozmus, D., Środek, D. and Szelęg, E. 2020. Pb-rich slags, minerals, and pollution resulted from a medieval $\mathrm{Ag}-\mathrm{Pb}$ smelting and mining operation in the Silesian-Cracovian region (southern Poland). Minerals 10, p. 28.

Cader et al. 2021a - Cader, J., Koneczna, R. and OlczaK, P. 2021a. The Impact of Economic, Energy, and Environmental Factors on the Development of the Hydrogen Economy. Energies 14(16), p. 4811.

CAder et al. 2021b - Cader, J., OlczaK, P. and Koneczna, R. 2021b. Regional dependencies of interest in the "My Electricity" photovoltaic subsidy program in Poland. Polityka Energetyczna - Energy Policy Journal 24(2), pp. 97-116.

Ciapala et al. 2021 - Ciapala, B., Jurasz, J., Janowski, M. and Kępińska, B. 2021. Climate factors influencing effective use of geothermal resources in SE Poland: the Lublin trough. Geotherm. Energy 9 , p. 3.

CSO 2020. Energy from renewable sources in 2019. Warsaw.

DAVIES, R. 2020. Peak performance: could mountains create long-term energy storage? Power Technol. [Online] https://power.nridigital.com/future_power_technology_feb20/peak_performance_could_mountains_create_long-term_energy_storage [Accessed: 2021-04-20].

Dychkovskyi et al. 2019 - Dychkovskyi, R., Tabachenko, M., Zhadiaieva, K. and Cabana, E. 2019. Some aspects of modern vision for geoenergy usage. E3S Web Conf. 123, 01010.

DyczKo, A. and Malec, M. 2021. Innovative Concept of Production Support System for the $\{$ LW $\}$ Bogdanka Mine. \{IOP\} Conf. Ser. Mater. Sci. Eng. 1134, 12004.

Energy Instrat 2021. No Title. [Online] https://www.energy.instrat.pl [Accessed: 2021-03-23].

Euractive 2021. EU's draft renewables law confirms 38-40\% target for 2030. [Online] https://www.euractiv.com/section/energy/news/leak-eus-draft-renewables-law-confirms-38-40-target-for-2030/ [Accessed: 2021-05-18]. 
European Commission 2019. Communication from the Commission to the European Parliament, the European Council, the Council, the European Economic and Social Committee and the Committee of the Regions. The European Green Deal. Brussels.

European Environmental Agency 2021. Share of energy consumption from renewable sources in Europe. EEA. [Online] https://www.eea.europa.eu/data-and-maps/indicators/renewable-gross-final-energyconsumption-5/assessment [Accessed: 2021-06-21].

FrANKOWSKI, J. 2020. Attention: Smog alert! Citizen engagement for clean air and its consequences for fuel poverty in Poland. Energy Build. 207, 109525.

Gawlik, L. ed. 2013. Coal for the Polish energy sector in the perspective of 2050 - scenario analyzes ( Wegiel dla polskiej energetyki w perspektywie 2050 roku - analizy scenariuszowe). Katowice: Górnicza Izba Przemysłowo-Handlowa (in Polish).

Graboś, A. and ŻymanowsKa-Kumon, S. 2014. Counteracting low emissions in dense residential areas (Przeciwdziałanie niskiej emisji na terenach zwartej zabudowy mieszkalnej) [ed.] R. Sadlok. Bochnia: HELIOS (in Polish).

Gravitricity 2020. Gravitricity. [Online] https://gravitricity.com/ [Accessed: 2021-07-27].

HOLDER, M. 2020. Gravitricity to pilot $£ 1 \mathrm{~m}$ gravity-based energy storage system in Edinburgh. Bus. Green. [Online] https://www.businessgreen.com/news/4015015/gravitricity-pilot-gbp-gravity-energy-storage -edinburgh [Accessed: 2021-07-22].

Hunt et al. 2020 - Hunt, J.D., Zakeri, B., Falchetta, G., Nascimento, A., WadA, Y. and Riahi, K. 2020. Mountain Gravity Energy Storage: A new solution for closing the gap between existing short- and longterm storage technologies. Energy 190, 116419.

Hussein et al. 2004 - Hussein, H.M.S., Ahmad, G.E. and El-Ghetany, H.H. 2004. Performance evaluation of photovoltaic modules at different tilt angles and orientations. Energy Convers. Manag. 45, pp. 2441-2452.

KadAR, P. 2014. Pros and Cons of the Renewable Energy Application. Acta Polytechnica Hungarica 11(4), pp. 211-224.

KamiŃSKI, P. 2021a. A New Method of Regulation of Loads Acting on the Shaft Lining in Sections Located in the Salt Rock Mass. Energies 14(1), p. 0042.

Kamiśski, P. 2021b. Development of New Mean of Individual Transport for Application in Underground Coal Mines. Energies 14(7), p. 2022.

KAMiŃski et al. 2021 - KAmiński, P., Dyczko, A. and Prostański, D. 2021. Virtual Simulations of a New Construction of the Artificial Shaft Bottom (Shaft Safety Platform) for Use in Mine Shafts. Energies $14(8), 2110$.

KASZYŃSKi et al. 2019 - KASZYŃSKI, P., KOMOROwSKA, A. and KAMiŃSKI, J. 2019. Regional distribution of hard coal consumption in the power sector under selected forecasts of EUA prices. Gospodarka Surowcami Mineralnymi - Mineral Resources Management 35(4), pp. 113-134.

Klojzy-KarczmarczyK, B. and MazureK, J. 2009. Local government responsibilities in the process of reducing low emission (Zadania samorząów lokalnych w procesie likwidacji niskiej emisji). Polityka Energetyczna 12(2.2), pp. 277-284 (in Polish).

Komorowska et al. 2020 - Komorowska, A., Benalcazar, P., Kaszyński, P. and Kamiński, J. 2020. Economic consequences of a capacity market implementation: The case of Poland. Energy Policy 144, 111683.

Kopacz et al. 2020 - Kopacz, M., Kulpa, J., Galica, D. and OlczaK, P. 2020. The influence of variability models for selected geological parameters on the resource base and economic efficiency measures Example of coking coal deposit. Resour. Policy 68, 101711.

Koval et al. 2019 - Koval, V., SRibna, Y., Mykolenko, O. and Vdovenko, N. 2019. Environmentalconcept of energy security solutions of local communities based on energy logistics. [In:] $19^{\text {th }}$ Internatio- 
nal Multidisciplinary Scientific GeoConference SGEM 2019, International Multidisciplinary Scientific GeoConference-SGEM. STEF92 Technology, 51 Alexander Malinov blvd, Sofia, 1712, Bulgaria, pp. 283-290.

Kryzia, D. and PeplowsKa, M. 2019. The impact of measures aimed at reducing low-stack emission in Poland on the energy efficiency and household emission of pollutants. Polityka Energetyczna - Energy Policy Journal 22(2), pp. 121-132.

KuBIŃSKI, K. and SZABŁOWSKI, Ł. 2020. Dynamic model of solar heating plant with seasonal thermal energy storage. Renew. Energy 145, pp. 2025-2033.

Kwestarz, M. 2016. Thermal energy storage - types of energy storage (Magazynowanie ciepla - rodzaje magazynów). Czysta Energ. 12, pp. 29-35 (in Polish).

Mangold, D. and Deschaintre, L. 2016. Seasonal thermal energy storage. Report on state of the art and necessary further R+D. [Online] http://task45.iea-shc.org/data/sites/1/publications/IEA_SHC_Task45_B_Report.pdf \{accessed: 2021.09.09].

Matuszewska et al. 2017 - Matuszewska, D., Kuta, M. and Górski, J. 2017. Cogeneration - Development and prospect in Polish energy sector. E3S Web Conf. 14, p. 01021.

Matuszewska et al. 2020 - MatuszewsKa, D., Kuta, M. and OlcZaK, P. 2020. Techno-Economic Assessment of Mobilized Thermal Energy Storage System Using Geothermal Source in Polish Conditions. Energies 13(13), p. 3404.

Matuszewska, D. and OlczaK, P. 2020. Evaluation of Using Gas Turbine to Increase Efficiency of the Organic Rankine Cycle (ORC). Energies 13(6), p. 1499.

Mikhno et al. 2021 - Mikhno, I., Koval, V., Shvets, G., Garmatiuk, O. and Tamosiuniene, R. 2021. Green Economy in Sustainable Development and Improvement of Resource Efficiency. Cent. Eur. Bus. Rev. 10, pp. 99-113.

Mirowski et al. 2020 - Mirowski, T., JaCh-Nocoń, M., JeloneK, I. and Nocoń, A. 2020. The new meaning of solid fuels from lignocellulosic biomass used in low-emission automatic pellet boilers. Polityka Energetyczna - Energy Policy Journal 23(1), pp. 75-86.

Mokrzycki, E. and Gawlik, L. 2013. Strategy for the security of energy resources in Poland-renewable energy sources. [In:] Environmental Engineering IV.

OlczaK, P. and Komorowska, A. 2021. An adjustable mounting rack or an additional PV panel? Cost and environmental analysis of a photovoltaic installation on a household: A case study in Poland. Sustain Energy Technol. Assessments 47, 101496.

Olczak et al. 2020 - Olczak, P., Matuszewska, D. and Kryzia, D. 2020. "Mój Prąd" as an example of the photovoltaic one off grant program in Poland. Polityka Energetyczna - Energy Policy Journal 23(2), pp. 123-138.

OlczaK et al. 2021a - OlczaK, P., JaŚKo, P., KryZia, D., MatusZewska, D., FyK, M.I. and DyczKo, A. 2021a. Analyses of duck curve phenomena potential in polish PV prosumer households' installations. Energy Reports 7, pp. 4609-4622.

OlczaK et al. 2021b - Olczak, P., Kryzia, D., Matuszewska, D. and Kuta, M. 2021b. "My Electricity" Program Effectiveness Supporting the Development of PV Installation in Poland. Energies 14(1), p. 0231.

OlczaK et al. 2021c - Olczak, P., Olek, M., Matuszewska, D., Dyczko, A. and Mania, T. 2021c. Monofacial and Bifacial Micro PV Installation as Element of Energy Transition - The Case of Poland Energies 14(2), p. 0499.

Orzee, B. 2020. Non-financial Value Creation Due to Non-financial Data Reporting Quality. Zesz. Nauk. Organ. i Zarzadzanie 148, pp. 605-617.

Palka, D. and StECula, K. 2019. Concept of technology assessment in coal mining. IOP Conf. Ser. Earth Environ. Sci. 261, 012038. 
Państwowy Instytut Geologiczny 2020. Balance of mineral deposits resources in Poland (Bilans zasobów złóż kopalin w Polsce). Warszawa: Państwowy Instytut Geologiczny (in Polish).

PAszkowski, W. and Loska, A. 2017. The use of data mining methods for the psychoacoustic assessment of noise in urban environment. Int. Multidiscip. Sci. GeoConference SGEM 17, pp. 1059-1066.

Pedchenko et al. 2018 - Pedchenko, M., Pedchenko, L., Nesterenko, T. and Dyczko, A. 2018. Technological Solutions for the Realization of NGH-Technology for Gas Transportation and Storage in Gas Hydrate Form. Solid State Phenom. 277, pp. 123-136.

Possemiers, M. 2014. Aquifer Thermal Energy Storage under different hydrochemical and hydrogeological conditions. [Online] https://limo.libis.be/primo-explore/fulldisplay?docid=LIRIAS1930575\&context $=$ L\&vid=Lirias\&search_scope $=$ Lirias\&tab=default_tab\&lang=en_US\&fromSitemap $=1$ [Accessed: 2021-09-09].

Rafat, K. and Grabowski, P. 2021. Energy storage (Magazynowanie energii). Academia-Mag. Pol. Akad. Nauk, DOI: 10.24425/academiaPAN.2021.136844 34-40 (in Polish).

REHAU 2011. Underground Thermal Energy Storage. Improving efficiency through seasonal heat storage. Canada.

Schmidt et al. 2018 - Schmidt, T., Pauschinger, T., Sørensen, P.A., Snijders, A., DJebbar, R., Boulter, R. and Thornton, J. 2018. Design Aspects for Large-scale Pit and Aquifer Thermal Energy Storage for District Heating and Cooling. Energy Procedia 149, pp. 585-594.

SoliŃSKI, J. 2004. Energy sector - world and Poland. Development 1971-2000, prospects to 2030.

Statistics Poland 2019. Energia ze źródet odnawialnych w 2018 roku. Informacje sygnalne.

Statistics Poland 2020a. Energy 2020. Warszawa.

Statistics Poland 2020b. Energia ze źródeł odnawialnych w 2019 roku. Informacje sygnalne.

SteCuŁa, K. 2018. Decision-making Dilemmas in Mining Enterprise and Environmental Issues, i. e. Green Thinking in Mining. $18^{\text {th }}$ Int. Multidiscip. Sci. Geoconference SGEM 2018, pp. 357-364.

Stecula, K. and Brodny, J. 2017a. Perspectives on renewable energy development as alternative to conventional energy in Poland. [In:] International Multidisciplinary Scientific GeoConference Surveying Geology and Mining Ecology Management, SGEM, pp. 717-724.

Stecula, K. and Brodny, J. 2017b. Generating knowledge about the downtime of the machines in the example of mining enterprise. [In:] International Multidisciplinary Scientific GeoConference Surveying Geology and Mining Ecology Management, SGEM, pp. 359-366.

Stecula, K. and Brodny, J. 2018a. Role and meaning of coal mining in Poland. [In:] International Multidisciplinary Scientific GeoConference Surveying Geology and Mining Ecology Management, SGEM. pp. 801-808.

Stecula, K. and Brodny, J. 2018b. Decision-making possibilities in the field of excavated material quality shaping in terms of environmental protection, I. E. how to be greener in mining. [In:] International Multidisciplinary Scientific GeoConference Surveying Geology and Mining Ecology Management, SGEM, pp. 243-250.

Stecula, K. and Tutak, M. 2018. Causes and effects of low-stack emission in selected regions of Poland. [In:] International Multidisciplinary Scientific GeoConference Surveying Geology and Mining Ecology Management, SGEM, pp. 357-364.

Steinmann et al. 2019 - Steinmann, W.-D., Bauer, D., Jockenhö̈fer, H. and JohnSon, M. 2019. Pumped thermal energy storage (PTES) as smart sector-coupling technology for heat and electricity. Energy 183, pp. 185-190.

WoźniaK, J. and Pactwa, K. 2018. Responsible Mining - The Impact of the Mining Industry in Poland on the Quality of Atmospheric Air. Sustainability 10, p. 1184.

Wróbel et al. 2019 - WróBel, J., SoŁtysik, M. and Rogus, R. 2019. Selected elements of the Neighborly Exchange of Energy - Profitability evaluation of the functional model. Polityka Energetyczna - Energy Policy Journal 22(4), pp. 53-64. 
WYRWICKI, G. 2004. Thermogravimetric analysis - unappreciated method for determination of rock type and quality (Analiza termograwimetryczna - niedoceniana metoda określania rodzaju i jakości kopaliny). Górnictwo Odkryw. 46, pp.120-125 (in Polish).

Żelazna et al. 2020 - Żelazna, A., Golębiowska, J., Zdyb, A. and Pawlowski, A. 2020. A hybrid vs. on-grid photovoltaic system: Multicriteria analysis of environmental, economic, and technical aspects in life cycle perspective. Energies 13(15), p. 3978.

\author{
Artur Dyczko, Paweł Kamiński, Kinga Stecula, Dariusz Prostański, \\ Michał Kopacz, Daniel Kowol
}

\title{
Magazynowanie energii cieplnej i mechanicznej jako szansa dla transformacji energetycznej w Polsce
}

\section{Streszczenie}

Celem Europejskiego Zielonego Ładu jest przekształcenie Europy w pierwszy na świecie kontynent neutralny dla klimatu do 2050 roku. Z tego względu kraje europejskie opracowują rozwiązania technologiczne zwiększające produkcję energii z odnawialnych źródeł. W celu powszechnego wdrożenia produkcji energii z odnawialnych źródeł energii konieczne jest rozwiązanie problemu magazynowania energii. Autorzy omówili problematykę magazynowania energii i odnawialnych źródeł energii, dokonując przeglądu stosowanych rozwiązań magazynowania energii cieplnej i mechanicznej. Odnieśli się do sektora energetycznego w Polsce, który opiera się głównie na działalności górniczej. Metodą, która została zastosowana w pracy, jest przegląd rozwiązań magazynowania energii cieplnej i mechanicznej. W praktyce przemysłowej na całym świecie opracowywane są różne rozwiązania w zakresie magazynowania energii. Autorzy dokonali ich przeglądu i opisali te, które obecnie funkcjonują w praktyce. W artykule przedstawione zostały dobre praktyki techniki magazynowania energii. Dodatkowo autorzy przeprowadzili analizę danych statystycznych dotyczących sektora energetycznego w Polsce. Zaprezentowali dane dotyczące produkcji energii pierwotnej w Polsce w latach 2004-2019 oraz opisali, jak zmieniały się one w czasie. Następnie przedstawili i zinterpretowali dane dotyczące odnawialnych źródeł energii w Polsce, a także sytuację Polski na tle innych krajów europejskich w kontekście udziału OZE w końcowym zużyciu energii brutto.

SŁowa KLUCzowe: magazynowanie energii, energia, odnawialne źródła energii, transformacja energetyczna, Polska 